Heri Setiawan, Budi Anna Keliat, Yossie Susanti Eka Putri

Asuhan Keperawatan Ners dan Ners Spesialis dengan Pendekatan Interpersonal Peplau

dan Caring Swanson Pada Klien Perilaku Kekerasan

\title{
ASUHAN KEPERAWATAN NERS DAN NERS SPESIALIS DENGAN PENDEKATAN INTERPERSONAL PEPLAU DAN CARING SWANSON PADA KLIEN PERILAKU KEKERASAN
}

\author{
Heri Setiawan$^{1}$, Budi Anna Keliat ${ }^{2}$, Yossie Susanti Eka Putri ${ }^{3}$ \\ ${ }^{1)}$ RSJ Prof Dr Soerojo Magelang, \\ 2),3) Fakultas Ilmu Keperawatan Universitas Indonesia
}

Korespondensi penulis: herirsjs09@yahoo.com

\begin{abstract}
Abstrak
Resiko perilaku kekerasan merupakan diagnosa keperawatan yang paling banyak ditemukan di Ruang Akut Rumah Sakit Jiwa Dr H Marzoeki Mahdi Bogor yaitu sebanyak 71,62\%, Tujuan penulisan artikel ini untuk menjelaskan mengetahui hasil asuhan keperawatan ners dan ners spesialis menggunakan pendekatan model teori interpersonal Peplau. Tindakan keperawatan ners diberikan pada individu, keluarga dan kelompok, tindakan keperawatan ners spesialis dilakukan dengan pemberian latihan asertif (AT) dan psikoedukasi keluarga (PEK). Metode yang digunakan yaitu analisis kasus. Analisis dilakukan pada 8 klien perilaku kekerasan dalam kurun waktu 16 Februari - 18 April 2016. Hasil pelaksanaan pemberian asuhan keperawatan di ruang akut rumah sakit jiwa menunjukan terjadinya penurunan tanda gejala klien perilaku kekerasan, peningkatan kemampuan klien dalam mengatasi perilaku kekerasan, dan peningkatan kemampuan keluarga dalam merawat anggota keluarga dengan perilaku kekerasan di ruang akut rumah sakit jiwa.
\end{abstract}

Kata kunci: perilaku kekerasan; ruang akut; tanda gejala; kemampuan

\section{PENDAHULUAN}

Kemampuan orang untuk beradaptasi terhadap stressor berbedabeda, tergantung dari sumber koping dan mekanisme koping seseorang untuk menanggap stressor tersebut, jika seseorang tersebut tersebut tidak bisa beradaptasi dengan baik maka akan jatuh ke perilaku maladaptif yang termasuk di dalamnya gangguan jiwa. Orang Dengan Gangguan Jiwa yang selanjutnya disingkat ODGJ adalah orang yang mengalami gangguan dalam pikiran, perilaku, dan perasaan yang tampak dalam bentuk sekumpulan tanda gejala dan atau perubahan perilaku yang bermakna pada klien ODGJ, serta dapat menimbulkan dampak pada kehidupan dan hambatan dalam menjalankan fungsi sebagai manusia (UU Kesehatan Jiwa No.18, 2014). Gangguan jiwa dapat membuat seseorang tidak bisa melakukan kegiatan sehari-hari dan tidak dapat mengambil keputusan sehingga klien gangguan jiwa tidak hidup sesuai dengan fungsinya (WHO, 2015).

Ketidakmampuan seseorang dalam menghadapi stressor yang ditandai dengan adanya penyimpangan pikiran, perasaan dan perilaku mengakibatkan klien tidak bisa menjalankan fungsi hidupnya secara normal. Perubahan fungsi hidup yang dialami oleh klien gangguan jiwa mempengaruhi kualitas hidup orang tersebut dan juga berdampak pula pada orang lain, dan juga lingkungan. Jumlah klien gangguan jiwa cukup banyak dialami oleh penduduk di dunia.

Gangguan jiwa dengan jumlah paling banyak yang di alami oleh penduduk di dunia adalah Skizofrenia. Data yang didapatkan menunjukan bahwa rata rata rasio penduduk dunia yang mengalami Skizofrenia yaitu 7 
Heri Setiawan, Budi Anna Keliat, Yossie Susanti Eka Putri

Asuhan Keperawatan Ners dan Ners Spesialis dengan Pendekatan Interpersonal Peplau dan

Caring Swanson Pada Klien Perilaku Kekerasan

berbanding 1000 penduduk di dunia atau sebesar kurang lebih 21 juta orang (WHO, 2015), tiga dari empat kasus gejala yang muncul terjadi pada usia 15 dan 34 tahun (Stuart, 2013). Hasil Riskesdas 2013, menunjukkan prevalensi angka gangguan jiwa berat secara nasional adalah $1,7 \%$ atau sekitar $3,022,600$ orang, atau $14,39 \%$ dari total klien skizofrenia di seluruh dunia (Riskesdas Kemenkes RI, 2013). Hal ini menunjukkan secara nasional angka gangguan jiwa berat cukup tinggi di Indonesia. Prevalensi gangguan jiwa berat di provinsi Jawa Barat adalah 1,6\% (Riskesdas Kemenkes RI, 2013). Prevalensi tersebut hampir sama dengan prevalensi gangguan jiwa berat secara nasional.

Perilaku kekerasan dapat terjadi pada klien dengan gangguan jiwa berat, Sebuah meta analisis dari 204 studi berdasarkan 166 data independen menemukan bahwa gejala gangguan jiwa berat berkaitan dengan peningkatan perilaku kekerasan sebesar 49-68\% (Silverstein et al. 2015). Hasil sistematik review pada 20 studi yang dilakukan, menemukan bahwa ada keterkaitan antara penderita Skizofrenia dengan perilaku kekerasan, dari 18.423 individu dengan gangguan Skizofrenia menunjukan peningkatan resiko perilaku kekerasan, perilaku kekerasan yang dilakukan oleh klien dengan Skizofrenia adalah 13,2\% dibandingkan dengan populasi pada umumnya yaitu sebesar 19,1 \%. Prevalensi perilaku kekerasan yang dilakukan oleh orang dengan Skizofrenia adalah 19,1\% (Swanson, 2006; Fazel, et all, 2009). Angka perilaku kekerasan yang dilakukan oleh klien skizofrenia tersebut lebih rendah dibandingkan dengan pada populasi pada umumnya.

Perilaku kekerasan terjadi karena tanda gejala positif seperti halusinasi.
Halusinasi klien dengan skizofrenia bisa menjadi pencetus terjadinya perilaku Halusinasi dapat menjadi suasana perasaan klien menjadi kurang baik, merasa kewalahan dengan halusinasi tersebut sehingga klien melakukan tindakan perilaku kekerasan. Pada umumnya perilaku kekerasan yang dilakukan oleh klien skizofenia berkaitan dengan gejala positif skizofrenia, daya tilik diri yang jelek, kondisi premorbid, pengaruh perilaku antisosial klien, dan psikopatologi kondisi akut (Volavka 2013). Kondisi psikopatologi pada klien skizofrenia mengakibatkan terjadinya perilaku kekerasan.

Perilaku kekerasan dilakukan secara verbal maupun nonverbal atau fisik. Perilaku kekerasan dalam bentuk verbal misalnya mengancam, sedangkan perilaku non verbal dilakukan dengan menyerang orang lain, memukul, menendang atau merusak lingkungan. Perilaku kekerasan yang dilakukan dalam bentuk kata-kata kasar sebanyak 60\% (Foster, Bowers, \& Nijman, 2007), melakukan tindakan kekerasan terhadap objek sebanyak $29 \%$ dan melakukan kekerasan terhadap diri sendiri sebanyak $19 \%$ (Bobes, Fillat \& Arango, 2009). Sedangkan perilaku maladaptif yang muncul pada klien dengan tanda gejala negatif seperti isolasi sosial adalah adanya percobaan bunuh diri (National Institue of Mental Health, 2009). Percobaan bunuh diri merupakan salah satu bentuk perilaku kekerasan pada diri sendiri. Tanda dan gejala yang khas pada klien skizofrenia yang dapat juga merugikan termasuk mencederai diri sendiri orang lain ataupun lingkungannya membuat tenaga kesehatan atau orang-orang di sekeliling klien memberikan penanganan khusus untuk mengatasi perilaku tersebut.

Upaya yang dilakukan untuk mengatasi klien resiko perilaku 
Heri Setiawan, Budi Anna Keliat, Yossie Susanti Eka Putri

Asuhan Keperawatan Ners dan Ners Spesialis dengan Pendekatan Interpersonal Peplau dan

Caring Swanson Pada Klien Perilaku Kekerasan

kekerasan dengan psikofarmaka dan pemberian asuhan keperawatan. Strategi pengobatan pada klien perilaku kekerasan pada fase agresif pada kondisi darurat adalah obat obatan antipsikotik atypikal yang dikombinasikan dengan golongan benzodiazepin, hal tersebut untuk meminimalkan efek ekstrapiramidal sindrom dan dapat memperbaiki psikopatologi secara global, kognitif, gejala negatif dan gangguan alam perasaan (Dixon \& Perkins 2010), kedua obat tersebut efektif pada penurunan gejala perilaku kekerasan secara cepat dan efektif. Klien dengan pemberian antipsikotik harus dikaji terlebih dahulu untuk mencegah terjadinya neuroleptik yang mengakibatkan kondisi yang lebih buruk, komplikasi dapat menyebabkan ketidaknyamanan pada klien (Stuart, 2013). Pemberian benzodiazepin dapat memberikan efek sedatif sehingga klien menjadi lebih tenang dan terjadi penurunan gejala perilaku kekerasan. Pemberian antipsikotik atypikal diberikan pada klien yang mempunyai potensi perilaku kekerasan, antipsikotik atypikal mempunyai efek ektrapiramidal yang sedikit (Stuart, 2013). Antipsikotik atypikal tersebut juga dapat diberikan dengan kombinasi lorazepam yang dapat memberikan efek sedatif. Sedangkan obat antipsikotik menurunkan gejala positif klien Skizofrenia. Upaya yang dilakukan pada klien dengan perilaku kekerasan bertujuan untuk mencegah terjadinya kekambuhan.

Penanganan kondisi krisis dilakukan di ruangan gawat darurat, apabila masih beresiko menunjukan perilaku kekerasan maka akan dilanjutkan di layanan rawat inap akut psikiatri. Tujuan layanan rawat inap akut psikiatri adalah untuk memberikan pemberian perlakuan yang manusiawi dengan standar tinggi dan memberikan perawatan dalam lingkungan yang aman dan terapeutik untuk orang yang mengalami gangguan jiwa (Rethink 2004), menurunkan gejala dan meningkatkan fungsi psikososial klien (Pitkanen 2010), dan remisi penyakit klien dengan berfokus pada gejala klien dan respon koping maladaptif pada klien (Stuart, 2013). Penanganan klien di Ruang akut psikiatri bertujuan untuk mencapai kondisi stabil klien dan meningkatkan koping adaptif klien dalam lingkungan yang terapeutik.

Tindakan keperawatan dilakukan di ruang akut berupa tindakan keperawatan ners dan ners spesialis pada klien dengan perilaku kekerasan. Pada pemberian tindakan ners yaitu berupa latihan nafas dalam, pukul bantal, minum obat teratur, bicara assertif, cara spiritual dan deeksalasi. Dari hasil penelitian menunjukan bahwa rata rata lama rawat klien kelompok intervensi yang diberikan tindakan ners adalah 23 hari sedangkan pada kelompok kontrol 40 hari. Klien pada kelompok intervensi mempunyai kemampuan secara mandiri sebesar $86,6 \%$ dan kemampuan dengan menggunakan bantuan sebesar 13,4\% dalam mencegah terjadinya perilaku kekerasan. (Keliat et al. 2009). Pada klien yang mempunyai kemampuan secara mandiri untuk mencegah terjadinya perilaku kekerasan mempunyai hari rawat lebih singkat secara bermakna apabila dibandingkan klien yang tidak memiliki kemampuan dalam mencegah perilaku kekerasan

Pemberian terapi spesialis yaitu latihan asertif, terapi ini efektif dalam menurunkan respons perilaku, kognitif, sosial dan fisik pada klien perilaku kekerasan (Wahyuningsih, Keliat, \& Hastono, 2009). Latihan asertif merupakan tindakan untuk melatih seseorang mencapai perilaku asertif (Kaplan \& Saddock, 2005). Latihan Asertif merupakan program latihan 
Heri Setiawan, Budi Anna Keliat, Yossie Susanti Eka Putri

Asuhan Keperawatan Ners dan Ners Spesialis dengan Pendekatan Interpersonal Peplau dan

Caring Swanson Pada Klien Perilaku Kekerasan

perilaku untuk melatih seseorang menyampaikan kebutuhan, hak, dan menentukan pilihan tanpa mengabaikan hak orang lain, Latihan asertif dikonseptualisasikan sebagai prosedur perilaku yang terstruktur untuk memfasilitasi perubahan perilaku dengan tepat secara sosial, ekspresif dan memunculkan adanya sebuah perilaku yang adaptif, dengan memperhatikan hak diri individu tanpa melanggar hak orang lain (Tobergte \& Curtis 2013).

Tindakan keperawatan pada keluarga berupa tindakan keperawatan ners dan ners spesialis berupa psikoedukasi keluarga. Terapi keluarga pada klien Risiko perilaku kekerasan bertujuan agar keluarga mampu merawat klien dengan Risiko perilaku kekerasan. Tindakan keperawatan yang diberikan adalah mendiskusikan bersama-sama keluarga mengenai masalah yang dihadapi keluarga dalam merawat klien dengan Risiko perilaku kekerasan. Selanjutnya mendiskusikan bersama-sama keluarga faktor-faktor yang menyebabkan Risiko perilaku kekerasan dan mendemonstrasikan cara merawat klien dengan Risiko perilaku kekerasan. Selain itu keluarga diajarkan mengenai pentingnya memberikan penghargaan dan pujian yang wajar atas upaya dan keberhasilan yang telah dilakukan dan dicapai oleh klien dan terus mendorong klien untuk melakukan kegiatan yang telah berhasil dilakukan klien. Langkah terakhir menyusun perencanaan pulang untuk klien. Dalam membuat perencanaan pulang keluarga membuat perencanaan kegiatan yang akan dilakukan klien selama dirumah (Keliat, 2010).

Tindakan keperawatan ners spesialis pada keluarga berupa psikoedukasi keluarga, psikoedukasi merupakan suatu alat terapi keluarga bertujuan untuk menurunkan faktor-faktor risiko yang berhubungan dengan perkembangan gejala-gejala perilaku. Psikoedukasi keluarga adalah salah satu element program perawatan kesehatan jiwa keluarga yang dilakukan dengan cara memberikan informasi dan edukasi melalui komunikasi yang therapeutik (Stuart, 2013).

Tahapan proses interpersonal yang dikembangkan Peplau dalan empat fase dinilai sangat relevan dengan manajemen kasus pada klien Resiko Perilaku Kekerasan khususnya di ruang akut, dimana klien berada di ruangan yang pertama di Rumah Sakit Jiwa. Teori Peplau yang berfokus pada interpersonal relationship ini sangat sesuai bagi intervensi pada klien dengan resiko perilaku kekerasan dalam mengaplikasikan terapi-terapi spesialis seperti terapi kognitif perilaku dan latihan asertif yang sangat membutuhkan hubungan yang trust dari klien kepada perawat sehingga klien bersedia mengungkapkan kebutuhan dan masalah yang dihadapi, pengalaman-pengalaman traumatik dan mengecewakan, termasuk harapan-harapan yang mungkin dirasakan klien belum tercapai sehingga klien merasa frustasi sehingga menunjukan respons perilaku kekerasan (Shives, 2009; Stuart, 2013). Konsep hubungan terapeutik perawat-klien sebagi dasar untuk memulainya seorang yang mengalami sakit memulai menerima dan mencoba berinteraksi dengan orang lain dan lingkungannya. Ketika seseorang mulai berani membina hubungan dengan orang lain, maka akan lebih mudah bagi seorang perawat menerapkan proses perawatan yang berkelanjutan berpijak pada kemampuan klien.

Penerapan teori keperawatan yang selanjutnya yaitu teori caring oleh Swanson, Theory of Caring dari Kristen M. Swanson: mendeskripsikan secara 
Heri Setiawan, Budi Anna Keliat, Yossie Susanti Eka Putri

Asuhan Keperawatan Ners dan Ners Spesialis dengan Pendekatan Interpersonal Peplau dan

Caring Swanson Pada Klien Perilaku Kekerasan

jelas pentingnya peran seorang perawat dalam meningkatkan kesehatan pada orang lain. Kristen M. Swanson mendefinisikan caring sebagai suatu cara dalam memelihara hubungan dengan seseorang atau pasien yang memiliki dan menganut nilai-nilai yang sama terhadap komitmen dan tanggung jawab. Teori caring ini peran perawat menurut Swanson (1987) adalah sebagai pemberi bantuan dan pelayanan dalam mencapai tingkat kesehatan dan kesejahteraan pada orang lain (Nursing as a informed Caring for Well-Being to Others). Berfokus pada fenomena utama dalam keperawatan yaitu individu/klien, kesehatan/kesejahteraan, lingkungan dan keperawatan.

Pemberian asuhan keperawatan pada klien perilaku kekerasan di Ruang Akut RSJ Dr H Marzoeki Mahdi Bogor selama 16 Februari hingga 18 April 2016 didapatkan bahwa diagnosa keperawatan yang paling banyak adalah Resiko Perilaku Kekerasan sebanyak 62 orang $(71,26 \%)$ dari 87 klien yang dirawat selama praktik. Pada karya ilmiah akhir ini akan dilaporkan mengenai hasil asuhan keperawatan ners dan ners spesialis pada 8 klien perilaku kekerasan dengan Asuhan keperawatan yang diberikan berupa tindakan keperawatan ners dan ners spesialis, asuhan keperawatan pada klien dilakukan bersama oleh ketua tim, perawat ruangan, mahasiswa ners dan mahasiswa ners spesialis, asuhan keperawatan ners dilakukan oleh ketua tim, perawat dan mahasiswa ners, sedangkan asuhan keperawatan ners spesialis dilakukan oleh mahasiswa.

\section{METODE}

Desain penelitian yang digunakan pada penelitian ini adalah dengan melakukan analisa kasus selama praktik klinik keperawatan jiwa pada 8 klien perilaku kekerasan di Ruang Akut Rumah Sakit Jiwa.

\section{HASIL}

Karakteristik klien dengan perilaku kekerasan dalam penelitian ini semuanya adalah laki-laki 8 orang $(100,0 \%)$. Pada jenjang pendidikan, sebagian besar jenjang pendidikannya adalah SMA 5 orang $(63,3 \%)$. Pada status pekerjaan, sebagian besar tidak bekerja 4 orang $(50 \%)$. Pada status pernikahan klien menunjukan sebagian besar sudah menikah 4 orang $(50 \%)$. Pada pemberian terapi medis yang diberikan saat ini, sebagian besar adalah golongan atypikal 5 orang $(63,3 \%)$, Berdasarkan riwayat anggota keluarga yang mengalami gangguan jiwa sebagian besar tidak ada riwayat anggota keluarga yang mengalami gangguan jiwa 6 orang $(73 \%)$. Karakteristik klien berdasarkan riwayat putus obat menunjukan sebagian besar mengalami putus obat yaitu sebanyak 7 orang $(77,8 \%)$. Berdasarkan usia rata-rata klien berusia 33 tahun, Analisis mengenai frekuensi dirawat klien dengan perilaku kekerasan rata-rata klien dirawat sebanyak 3 kali, rata-rata klien mengalami gangguan jiwa selama 4 tahun.

Perubahan tanda gejala dilihat pada tabel berikut ini:

Tabel 1. Perubahan Respons (Tanda Gejala) pada klien perilaku kekerasan di Ruang Kresna RSMM setelah pemberian tindakan ners klien, keluarga, TAK, AT, dan psikoedukasi

16 Februari-18 April 2016 (n=9)

\begin{tabular}{llllc}
\hline No & Respons & Pre & Post & $\begin{array}{c}\text { Penur } \\
\text { unan }\end{array}$ \\
\hline 1. & Kognitif & & & \\
\hline & $\begin{array}{l}\text { Mempunyai pikiran } \\
\text { negatif }\end{array}$ & 8 & 2 & 6 \\
& Pikiran curiga & 6 & 2 & 4 \\
\hline $\begin{array}{l}\text { Meremehkan } \\
\text { keputusan }\end{array}$ & 8 & 1 & 7 \\
& Perubahan isi pikir & 1 & 0 & 1 \\
\hline $\begin{array}{l}\text { Pikiran ingin } \\
\text { memukul orang }\end{array}$ & 6 & 2 & 4 \\
\hline 2. & & & \\
\hline & Mfektif & 8 & 2 & 6 \\
\hline
\end{tabular}


Heri Setiawan, Budi Anna Keliat, Yossie Susanti Eka Putri

Asuhan Keperawatan Ners dan Ners Spesialis dengan Pendekatan Interpersonal Peplau dan

Caring Swanson Pada Klien Perilaku Kekerasan

\begin{tabular}{|c|c|c|c|c|}
\hline & nyaman & & & \\
\hline & Afek labil & 8 & 2 & 6 \\
\hline & Kecewa & 6 & 1 & 5 \\
\hline & Kesal/jengkel & 6 & 1 & 5 \\
\hline \multirow[t]{9}{*}{3.} & Fisiologis & & & \\
\hline & Tensi meningkat & 7 & 2 & 5 \\
\hline & Nadi meningkat & 7 & 2 & 5 \\
\hline & $\begin{array}{l}\text { Pernafasan } \\
\text { meningkat }\end{array}$ & 8 & 2 & 6 \\
\hline & Wajah merah & 8 & 4 & 4 \\
\hline & $\begin{array}{l}\text { Gangguan istirahat } \\
\text { tidur }\end{array}$ & 8 & 3 & 5 \\
\hline & Saliva meningkat & 3 & 2 & 1 \\
\hline & $\begin{array}{l}\text { Perubahan nafsu } \\
\text { makan }\end{array}$ & 3 & 2 & 1 \\
\hline & Berkeringat & 3 & 1 & 2 \\
\hline \multirow[t]{14}{*}{4.} & Perilaku & & & \\
\hline & $\begin{array}{l}\text { Mendominasi } \\
\text { pembicaraan }\end{array}$ & 8 & 1 & 7 \\
\hline & Mondar-mandir & 5 & 1 & 4 \\
\hline & $\begin{array}{l}\text { Melempar/memukul } \\
\text { benda/orang }\end{array}$ & 5 & 1 & 4 \\
\hline & Agresif & 5 & 1 & 4 \\
\hline & Pasif & 6 & 4 & 2 \\
\hline & $\begin{array}{l}\text { Mengepalkan } \\
\text { tangan }\end{array}$ & 6 & 2 & 4 \\
\hline & Nada suara tinggi & 5 & 2 & 3 \\
\hline & Teraik-teriak & 6 & 2 & 4 \\
\hline & Bicara kasar/kotor & 6 & 2 & 4 \\
\hline & Meludah & 5 & 2 & 3 \\
\hline & Melotot & 6 & 2 & 4 \\
\hline & Memukul & 7 & 2 & 5 \\
\hline & Pandangan tajam & 8 & 3 & 5 \\
\hline \multirow[t]{4}{*}{5.} & Sosial & & & \\
\hline & $\begin{array}{l}\text { Menarik } \\
\text { diri/pengasingan }\end{array}$ & 8 & 3 & 5 \\
\hline & Bermusuhan & 7 & 3 & 4 \\
\hline & Penolakan & 6 & 2 & 4 \\
\hline
\end{tabular}

tanda gejala sosial: menarik diri sebanyak 5 orang.

Latihan asertif merupakan tindakan untuk melatih seseorang mencapai perilaku asertif (Kaplan \& Saddock, 2005). Latihan asertif merupakan program latihan perilaku untuk melatih seseorang menyampaikan kebutuhan, hak, dan menentukan pilihan tanpa mengabaikan hak orang lain (Forkas,1997). Menurut Hopkins (2005), Latihan asertif yaitu terapi untuk melatih kemampuan seseorang untuk mengungkapkan pendapat, perasaan, sikap dan hak tanpa disertai adanya perasaan cemas. Assertiveness merupakan kemampuan untuk mengungkapkan pikiran dan perasaan dengan nyaman dan percaya diri, jujur, terbuka dan menghargai diri sendiri dan menghormati orang lain (Riley, 2000 dalam Fortinash, 2004).

Perilaku asertif adalah perilaku yang meningkatkan kualitas hubungan antar manusia, memungkinkan untuk bertindak dengan cara yang terbaik, membuat perasaan lebih baik tanpa adanya rasa cemas, mengekspresikan perasaan secara jujur dan nyaman, dan dapat melaksanakan hak pribadi tanpa menyangkal hak orang lain (Townsend, 2009). Perilaku asertif adalah suatu dasar kemampuan interpersonal seseorang yang meliputi berbagai hal sebagai berikut: (1) berkomunikasi secara langsung dengan orang lain, (2) dapat mengatakan tidak terhadap suatu permintaan yang tidak rasional, (3) mampu untuk menyampaikan perasaannya, dan (4) mengekspresikan penghargaan kepada orang lain sesuai dengan situasi atau kondisi seseorang (5) menerima pujian dari orang lain (Stuart, 2013). Dengan demikian dapat disimpulkan perilaku asertif dapat membuat seseorang merasa nyaman, baik ketika menyampaikan perasaannya 
Heri Setiawan, Budi Anna Keliat, Yossie Susanti Eka Putri

Asuhan Keperawatan Ners dan Ners Spesialis dengan Pendekatan Interpersonal Peplau dan

Caring Swanson Pada Klien Perilaku Kekerasan

dan mengungkapkan pendapatnya maupun ketika orang lain menyampaikan perasaan dan pendapatnya serta dapat membuat seseorang berkomunikasi dengan orang lain tanpa adanya perasaan marah.

Pada latihan asertif klien belajar mengungkapkan rasa marah secara tepat atau asertif sehingga klien mampu untuk berhubungan dengan orang lain, mampu menyatakan: apa yang diinginkannya, apa yang disukainya, dan apa yang ingin dia kerjakan dan kemampuan untuk membuat seseorang merasa tidak risih berbicara tentang dirinya sendiri. Teknik ini digunakan untuk melatih klien yang mengalami kesulitan untuk menyatakan diri bahwa tindakannya adalah layak atau benar. Latihan ini terutama berguna di antaranya untuk membantu individu yang tidak mampu mengungkapkan perasaan tersinggung, kesulitan menyatakan tidak, mengungkapkan afeksi dan respon posistif lainnya. Cara yang digunakan adalah dengan permainan peran dengan bimbingan konselor. Diskusi-diskusi kelompok juga dapat diterapkan dalam latihan asertif ini.

Teori konseptual peplau (1992) terdapat kerangka konsep kerja dimana perawat dapat mengkaji, merencanakan, dan intervensi untuk mendapatkan outcome pasien. Perawat adalah individu yang kompleks, dan klien juga merupakan individu yang komplek, dimana memiliki kepribadian yang unik dan pengetahuannya dengan kerangka berpikirnya (Peplau (1992)(Marchese 2006). Tujuan keperawatan adalah untuk mendidik klien dan keluarga dan untuk membantu klien mencapai kematangan perkembangan kepribadian. Oleh sebab itu, perawat berupaya mengembangkan hubungan perawat dan klien melalui peran yang diembannya (nara sumber, konselor, dan wali). Adapun kerangka kerja praktik dari teori Peplau memaparkan bahwa keperawatan adalah proses yang penting, terapeutik, dan interpersonal. Keperawatan berpartisipasi dalam menyusun struktur system asuhan kesehatan untuk menfasilitasi kondisi yang alami dari kecenderungan manusia untuk mengembangkan hubungan interpersonal.

Pada pemberian paket tindakan yang pertama diberikan tindakan keperawatan keluarga, Terapi keluarga pada klien Risiko perilaku kekerasan bertujuan agar keluarga mampu merawat klien dengan Risiko perilaku kekerasan. Tindakan keperawatan yang diberikan adalah mendiskusikan bersama-sama keluarga mengenai masalah yang dihadapi keluarga dalam merawat klien dengan Risiko perilaku kekerasan. Selanjutnya mendiskusikan bersama-sama keluarga faktor-faktor yang menyebabkan Risiko perilaku kekerasan dan mendemonstrasikan cara merawat klien dengan Risiko perilaku kekerasan. Selain itu keluarga diajarkan mengenai pentingnya memberikan penghargaan dan pujian yang wajar atas upaya dan keberhasilan yang telah dilakukan dan dicapai oleh klien dan terus mendorong klien untuk melakukan kegiatan yang telah berhasil dilakukan klien. Langkah terakhir menyusun perencanaan pulang untuk klien. Dalam membuat perencanaan pulang keluarga membuat perencanaan kegiatan yang akan dilakukan klien selama dirumah (Keliat, 2010). Kegiatan yang dilakukan bertujuan agar keluarga tidak hanya mampu secara kognitif tapi keluarga juga mampu mempraktekkan dan melakukan cara merawat klien dengan Risiko perilaku kekerasan bila klien telah pulang kerumah.

Keluarga diharapkan mampu mendiskusikan masalah yang dirasakan 
Heri Setiawan, Budi Anna Keliat, Yossie Susanti Eka Putri

Asuhan Keperawatan Ners dan Ners Spesialis dengan Pendekatan Interpersonal Peplau dan

Caring Swanson Pada Klien Perilaku Kekerasan

dalam merawat klien, mampu memahami penyebab, proses terjadi, tanda dan gejala, serta akibat perilaku kekerasan, mampu merawat anggota keluarga dengan perilaku kekerasan, mampu ikut serta ketika klien sedang dilatih terapi, mampu memotivasi klien melakukan tarik nafas, pukul kasur bantal, berdoa, minum obat, bicara yang baik, menceritakan tentang kemarahannya (Keliat, 2011). Hasil penelitian yang dilakukan terkait dengan tindakan ners pada keluarga dengan anggota keluarga yang mengalami perilaku kekerasan di ruang MPKP menunjukan terjadi penurunan tanda gejala klien perilaku kekerasan dan peningkatan kemampuan keluarga dalam merawat anggota keluarga yang mengalami perilaku kekerasan (Akbar, Keliat, \& Akemat, 2014). Kemampuan keluarga dalam merawat anggota keluarga yang mengalami perilaku kekerasan dapat mencegah kekambuhan.

Psikoedukasi keluarga merupakan suatu alat terapi keluarga bertujuan untuk menurunkan faktor-faktor risiko yang berhubungan dengan perkembangan gejala-gejala perilaku. FPE adalah salah satu element program perawatan kesehatan jiwa keluarga yang dilakukan dengan cara memberikan informasi dan edukasi melalui komunikasi yang therapeutik (Stuart, 2013). Psikoedukasi keluarga bertujuan untuk berbagi informasi tentang perawatan kesehatan jiwa (Varcarolis, 2006). Tujuan pemberian terapi ini adalah untuk mengurangi dan mencegah kekambuhan klien serta mempersiapkan klien kembali kedalam lingkungan keluarga dan masyarakat dengan memberikan ketrampilan dan penghargaan terhadap fungsi sosial dan ocupasi klien selain itu tujuan lainnya adalah memberikan dukungan terhadap anggota keluarga dalam dalam menguranggi beban keluarga terutama beban fisik dan mental dalam merawat klien dengan gangguan jiwa dalam waktu yang lama (Niven, 2002).

Peran perawat dalam family psychoeducation therapy meliputi lima komponen yaitu memberikan informasi terkait gangguan jiwa khususnya dalam merawat klien dengan Risiko perilaku kekerasan, melatih keluarga dalam menyelesaikan konflik yang terjadi di dalam keluarga, memberi kesempatan dalam memvalidasi perasaan klien dan keluarga terkait dengan keyakinan dan sumber-sumber pendukung dalam melakukan aktivitas sosial dan interaksi sosial klien, meningkatkan koping keluarga dalam menghadapi klien dengan gangguan jiwa, dan meningkatkan penggunaan dukungan formal atau informal bagi klien dan keluarga. Selain itu dalam Family system therapy pemberian dukungan keluarga merupakan salah satu alternatif terapi yang dapat diberikan pada keluarga, sebagaimana terapi yang disarankan oleh Dochterman (2004) yang menyatakan bahwa, terapi ini membantu keluarga mengidentifikasi dukungan dari keluarga terhadap klien dan menyediakan sumbersumber yang dimiliki keluarga. Dalam family system therapy perawat memfasilitasi sistem keluarga dalam menentukan peran, harapan peran, penyelesaian konflik, membantu anggota keluarga mengklarifikasi kebutuhan dalam berhubungan dengan diri sendiri, orang lain, lingkungan dan zat yang lebih tinggi.

\section{KESIMPULAN}

Karakteristik klien dengan perilaku kekerasan dalam penelitian ini lebih banyak laki-laki. Pada jenjang pendidikan, sebagian besar jenjang pendidikannya adalah SMA. Pada status pekerjaan, sebagian besar tidak bekerja. 
Heri Setiawan, Budi Anna Keliat, Yossie Susanti Eka Putri

Asuhan Keperawatan Ners dan Ners Spesialis dengan Pendekatan Interpersonal Peplau dan

Caring Swanson Pada Klien Perilaku Kekerasan

Pada status pernikahan klien menunjukan sebagian besar sudah menikah. Pada pemberian terapi medis yang diberikan saat ini, sebagian besar adalah golongan typikal. Berdasarkan riwayat anggota keluarga yang mengalami gangguan jiwa sebagian besar tidak ada riwayat anggota keluarga yang mengalami gangguan jiwa.

Karakteristik berdasarkan keberhasilan pengobatan sebelumnya sebagian besar tidak berhasil. Karakteristik klien berdasarkan riwayat putus obat menunjukan sebagian besar mengalami putus obat. Berdasarkan usia rata-rata klien masuk dalam usia dewasa, Analisis mengenai frekuensi dirawat klien dengan perilaku kekerasan rata-rata klien dirawat sebanyak tiga kali, ratarata klien mengalami gangguan jiwa selama dua sampai tiga tahun. Pemberian tindakan keperawatan ners dan ners spesialis efektif dalam menurunkan ta nda gejala perilaku kekerasan di ruang akut rumah sakit jiwa.

Perawat jiwa di rumah sakit diharapkan selalu memotivasi klien dan mengevaluasi kemampuan-kemampuan yang telah dipelajari dan dimiliki oleh klien sehingga latihan yang diberikan membudaya. Apabila terjadi kemunduran pada klien hendaknya perawat ruangan mengkonsultasikan perkembangan kliennya yang telah mendapat terapi spesialis kepada perawat spesialis yang dimiliki rumah sakit.

Hasil penelitian ini hendaknya digunakan sebagai evidence based dalam mengembangkan tindakan keperawatan ners dan ners spesialis berupa AT, sehingga menjadi modalitas terapi keperawatan jiwa yang efektif dalam mengatasi masalah kesehatan jiwa dan meningkatkan derajat kesehatan jiwa. Penelitian lebih lanjut perlu dilakukan pada klien dengan perilaku kekerasan dengan cohort untuk melihat pencapaian kemampuan dalam menurunkan gejala dan meningkatkan kemampuan mengontrol perilaku kekerasan (relaksasi, mengubah pikiran negatif, keyakinan irasional dan perilaku negatif).

\section{DAFTAR PUSTAKA}

Akbar, Keliat, Akemat. (2014). Hubungan Pelaksanaan MPKP terhadap hasil asuhan keperawatan pada pasien dan keluarga di RS Tampan. Tesis. FIK UI

Balitbang depkes RI. (2013). Hasil Riset Kesehatan Dasar 2013, Jakarta : depkes RI.

Bobes, J., Fillat, O \& Arango, C. (2009). Violence among schizophrenia outpatient compliant with medication: prevalence assosiated factor. Acta psychiatrica scandinavica, 199, 218-225

Dixon, L.B. \& Perkins, D.O. (2010). Treatment of Patients With Schizophrenia Second Edition.

Dochterman . (2004). Nursing intervention classification $\quad\left(4^{\text {th }}\right.$ edition) St.louis. Mosby

Fazel, S, et all. (2009). Schizophrenia and Violence: Systematic Review and Meta-Analysis. Plos Medicine

Forkas, W.M. (1997). Assertiveness Training With Individuals Who Are Moderately and Mildly Retarded Psikologi, University Pasific Stockton, Carlifornia

Fosters, C, Bowers L, Nijman, H. (2007). Aggressive behavior on acute psychiatric wards: prevalence, severity and management: journal of advanced nursing 58 (2): 140-9

Hodgins, S. (2008). Violent behaviour among people with schizophrenia: a framework for investigations of causes, and effective treatment, and 
Heri Setiawan, Budi Anna Keliat, Yossie Susanti Eka Putri

Asuhan Keperawatan Ners dan Ners Spesialis dengan Pendekatan Interpersonal Peplau dan

Caring Swanson Pada Klien Perilaku Kekerasan

prevention. The Royal Society Publishing

Hopkins, S. (2008). Violent behaviour among people with schizophrenia: a framework for investigations of causes, and effective treatment, and prevention. The Royal Society Publishing

Kaplan H.I, Sadock B.J, Grebb J.A. (2005). Sinopsis Psikiatri Jilid 1. Edisi ke-7. Terjemahan Widjaja Kusuma. Jakarta: Binarupa Aksara. p. 86-108.

Keliat, B. et al. (2009). Influence of the abilities in controlling violence behavior to the length of stay of schizophrenic clients in Bogor mental hospital, Indonesia. Med J Indones, 18(1), pp.31-35. Available at:

http://mji.ui.ac.id/journal/index.php/ mji/article/view/336.

Keliat, BA, \& Akemat. (2010). Model Praktik Keperawatan Profesional Jiwa. Jakarta : EGC.

Marchese, K. (2006). Using Peplau' s Theory of Interpersonal Relations to Guide Undergoing Urinary Diversion. Urologic Nursing, 26(5), pp.363-372.

Niven. (2002). Editor Monica Ester. Psikologi kesehatan : pengantar untuk perawat dan profesi kesehatan lain. Edisi 2. Jakarta : EGC

Pitkanen, A. (2010). Thesis: Improving Quality Of Life Of Patients With Schizophrenia,

Rethink. (2004). Behind Closed Doors: The current state and future vision of acute mental health care in the UK. Available at: file:///D:/THESIS/literature/behindclosed-doors-reportpdf.pdf.

Silverstein, S.M. et al. (2015). O Press. realities and recommendations. Crime Psychology Review, 1(1), pp.21-42. Available at: http://dx.doi.org/10.1080/23744006. 2015.1033154.

Stuart, GW. (2013). Principles and practice of psychiatric nursing. (9th edition). St Louis : Mosby.Tobergte, D.R. \& Curtis, S., 2013. No Title No Title. Journal of Chemical Information and Modeling, 53(9), pp.1689-1699.

Swanson, et al. (2006). A National Study of Violent Behavior in Persons With Schizophrenia. Arch Gen Psychiatry/Vol 63, May 2006

Townsend, CM. (2009). Psychiatric mental health nursing Concept of care in evidence base practice. (6th Ed.). Philadelphia: F.A. Davis Company.

Tobergte, D. R., \& Curtis, S. (2013). No Title No Title. Journal of Chemical Information and Modeling, 53(9), 1689-1699.

http://doi.org/10.1017/CBO9781107 415324.004

Undang Undang RI nomor 18. (2014). Tentang Kesehatan Jiwa.

Videback, SL. (2008).Buku Saku Keperawatan Jiwa. EGC: Jakarta

Volavka, J. (2013). Violence in schizophrenia and bipolar disorder. , 25(1), pp.24-33.

Wahyuningsih, Keliat, \& Hastono. (2009). pengaruh Assertiveness Training terhadap perilaku kekerasan pada klien skizofrenia di RSUD Banyumas. Tesis: 2009

World Health Organization. (2015). Improving health systems and services for mental health (Mental health policy and service guidance package), Geneva27, Switzerland : WH 